\title{
Comparison of organic and conventional crop yields in Austria
}

\author{
Vergleich von Erträgen aus dem biologischen und dem konventionellen \\ Ackerbau in Österreich
}

\author{
Martin Brückler ${ }^{1 *}$, Thomas Resl ${ }^{1}$, Andreas Reindl ${ }^{1}$ \\ ${ }^{1}$ Federal Institute of Agricultural Economics (AWI), Marxergasse 2, 1030 Vienna, Austria \\ * Corresponding author: martin.brueckler@awi.bmnt.gv.at
}

Received: 11 November 2017, received in revised form: 22 December 2017, accepted: 11 January 2018

\begin{abstract}
Summary
Organic farming represents an integral part of agriculture in Austria. The share of organic holdings and the share of area being organically farmed are already high relative to other countries within the European Union. So far, analyses of the organic sector have mainly focused on the economic output and the utilised area; less is known about absolute crop yields per hectare and the gap between organic and conventional crop yields. Given their relevance for profitability calculations and production strategies, such data is of major interest for farmers, advisors, and decision-makers. To address this lack of knowledge, we combine the Austrian farm accountancy data and Integrated Administration and Control System data for Austria. This paper presents a statistical analysis of organic crop yield data for the national Austrian territory as well as for regional categories and covers the period from 2003-2016. The results show a significant difference in crop yields: i) between organic and conventional farming systems; ii) between regional categories in Austria. Organic cereals achieve 35\% lower average crop yields than conventional systems, yields for organic root and tuber crops were $27-49 \%$ lower. Yield gaps of oilseed and protein crops vary widely between respective crop species.
\end{abstract}

Keywords: organic farming, conventional farming, crop yields, accountancy data, yield gaps

\section{Zusammenfassung}

Der biologische Landbau stellt einen wesentlichen Teil der österreichischen Landwirtschaft dar. So sind die Anteile an biologischen Betrieben als auch an biologisch bewirtschafteten Flächen im Vergleich mit anderen Staaten innerhalb der Europäischen Union sehr hoch. Bisherige Betrachtungen des biologischen Landbaus fokussierten hauptsächlich auf ökonomischen Auswertungen und der bewirtschafteten Fläche. Zu den erwirtschafteten Erträgen pro Hektar sowie zu den Unterschieden der Erträge im Vergleich mit dem konventionellen Landbau sind jedoch nur wenige Informationen verfügbar. Als Grundlage für betriebswirtschaftliche Berechnungen und Produktionsentscheidungen sind diese jedoch für Landwirte, Berater und Entscheidungsträger von großer Bedeutung. Um die Datenverfügbarkeit diesbezüglich zu verbessern, werden in dieser Studie statistische Analysen der biologischen Erträge für Österreich dargestellt und mit konventionellen verglichen. Als Basis dafür dient das System der freiwillig buchführenden Betriebe in Verbindung mit dem Invekos-Datensatz für Österreich im Zeitraum 2003 bis 2016. Die Ergebnisse zeigen signifikante Unterschiede zwischen Erträgen im biologischen und konventionellen Ackerbau, als auch zwischen regionalen Kategorien. So liegen durchschnittliche Erträge bei Bio-Getreide um die 35 \% niedriger als bei konventionellen, Bio-Hackfrüchte erzielten 27-49 \% niedrigere Erträge. Bei Ölsaaten variieren die Mengenertragsunterschiede stark nach jeweiliger Feldfrucht.

Schlagworte: Biolandbau, konventioneller Landbau, Erträge, Buchführungsdaten, Ertragsunterschiede 


\section{Introduction}

Over the past 25 years, organic farming systems have increased rapidly in Austria. Both the share of organic holdings in total holdings and the share of area organically farmed in total utilised agricultural area (UAA) are among the highest in the European Union (EU) and represent $19 \%$ and $22 \%$ respectively (EC, 2013; BMFLUW, 2017a). In absolute terms, this equalled 20,820 organic farms and 463,256 ha of organic agricultural area (excluding alpine and mountainous regions) in 2016. The area of arable land amounts to 205,706 ha and grassland to 248,709 ha (BMFLUW, 2017b). Most notable is the vast expansion of the organic arable land, which has tripled since the year 2000. The reason for this is the numerous conversions of arable farms. In particular, large cash crop farms switched from conventional to organic production systems. Organic farming systems might be more profitable due to contract farming and the area specific incentives of agri-environmental programs, along with other payments schemes of the CAP (Groier, 2013). However, public discussion regarding the productivity of the organic crop production is increasing, given the relatively large proportion of organic farming in Austrian agriculture.

In this context, the term productivity is wide-ranging, considering the multifunctional services provided by organic farming systems. Organic farming has been shown to have higher soil carbon stocks, efficient nutrient $(\mathrm{N}, \mathrm{P}, \mathrm{K})$ utilisation, less nitrogen and phosphorus leaching and positive effects on species richness (Mäder et al., 2002; Mondelaers et al., 2009; Gattinger et al., 2012; Tuck et al., 2014; Herndl et al., 2016). Although, often cited lower crop yields and the corresponding demand for additional arable land as well as the requirement to regenerate the fertility of land might reduce the effects mentioned above (Tuomisto et al., 2012; Gabriel, 2013; Noleppa, 2016). From a socio-economic perspective, operating organic farms tend to be more labour-intensive. Contrarily, average agricultural incomes are higher for organic farms compared to conventional farms. This may result from higher producer prices and organic specific subsidy payments (Groier, 2016), which depend on the operational structure and management form of organic and conventional farms compared (Schneeberger et al., 2005). Hence, for economic and ecological reasons, we assume the harvested crop yields per area to be the central variable for the productivity of crop production.

Several studies have been carried out to compare differences between organic and conventional crop yields, affirm- ing organic crop yields to be lower. Two often-cited studies comparing the relative crop yield levels of organic and conventional farming are De Ponti et al. (2012) and Seufert et al. (2012). These meta-analyses found organic crop yields to be $80 \%$ and $75 \%$ of conventional crop yields, respectively. In a long-term field trial, Mäder et al. (2002) also identified that mean organic crop yields are $20 \%$ lower (the field trial has been conducted by the Research Institute of Organic Agriculture (FIBL) Switzerland since 1978). A similar long-term field trial, conducted by FIBL Austria and the University of Life Sciences and Natural Resources, Vienna (BOKU), was established in Austria in 2003. For the rest of Europe, the level of organic cereal crops is estimated to be 60 to $70 \%$ of the conventional cereal crops (Mäder et al., 2002). Owing to the high productivity of conventional farming, yield gaps in Germany and lowland England are typically even higher. A comparison of organic and conventional farms of the German farm accountancy data network indicated 53\% lower crop yields for cereals, $56 \%$ lower for wheat and $42 \%$ lower for potatoes (Osterburg et al., 2013). This is in line with the results published by Von Witzke and Noleppa (2013), who reported organic crop yields to be 30 to $50 \%$ lower, and data analysed by Gabriel et al. (2013) for England.

For Austria, previous studies mainly focused on the economic situation, the quantitative development of organic farms and the area under organic farming (see Schneeberger, 2005; Eder, 2006; Darnhofer, 2009; Groier 2013). Data for organic crop yields has been published in the annual statistical report of the Austrian Federal Ministry of Agriculture, Forestry, Environment and Water Management, covering average crop yields of a small selected number of crop species between 2005 and 2010 (BMLFUW, 2011). In addition, field trials all over the country focusing on organic crops are being carried out by the Austrian Chambers of Agriculture, FIBL Austria and BOKU, Vienna. Moreover, there will be annual statistics about organic crop yields throughout Austria from the year 2017 onwards, published by the Austrian Market Organisation and Paying Agency for Agriculture and Rural Development (AMA). Nevertheless, holistic data on organic crop yields independently of and in comparison with conventional crop yields is currently neither available at nationwide nor regional level. Agricultural advisors, farmers and decisions-makers depend on such organic crop yield data in order to increase the organic market transparency, select production strategies with high revenue efficiency and further develop the organic market sector. 
To counter this lack of information, this paper aims to establish a knowledge database on crop yield data of organic farming in Austria. We put the emphasis on the yield gaps between organic and conventional farming and further knowledge on nationwide crop yields per crop type (cereals, root and tuber crops, and oilseed and protein crops) and crop species (e.g., wheat, rye, potatoes). Additionally, comprehensive information about the crop yield differences between regional categories shall be provided. In section 2 , we conduct statistical analyses of organic crop yield data and compare organic and conventional crop yields at the national level (Austria) and based on regional categories. Section 3 presents and discusses our results. We conclude with an interpretation of our findings and an outlook for future research.

\section{Data and Methods}

To analyse the crop yield data, we perform two independent analyses. First, we employ the classification of the arable land based on the eight major agricultural production areas in Austria (Hochalpen, Voralpen, Alpenostrand, Wald- and Mühlviertel, Kärntner Becken, Alpenvorland, Südöstliches Flach- and Hügelland, Nordöstliches Flach- and Hügelland). Secondly, we classify the arable land into climatic agricultural areas by grouping them into dry, occasionally dry and humid areas. We then calculate the average organic and conventional crop yields and apply statistical tests.

\subsection{Data}

We use the Austrian Farm Accountancy Data set between 2003-2016, which is a representative survey of commercial agricultural and forestry holdings in Austria. This survey also forms the basis for the Austrian part of the Farm Accountancy Data Network (FADN) survey of the European Union. The sample size covers about 2,200 holdings in total per year, of which 494 were organic holdings in 2016. The survey is classified according to the key production activities and economic sizes, and therefore, is only representative for these factors. For our analysis, we derive the organic and conventional crop yields (in $100 \mathrm{~kg}$ per hectare $[\mathrm{dt} / \mathrm{ha}]$ ) out of this survey. The crop yields belong to 14 different crop species, which we group in three crop types. These include cereals (eight species), root and tuber crops (two species), as well as, oilseed and protein crops (four species). The survey records the crop yield data per holding on an annual basis. Organic holdings are slightly

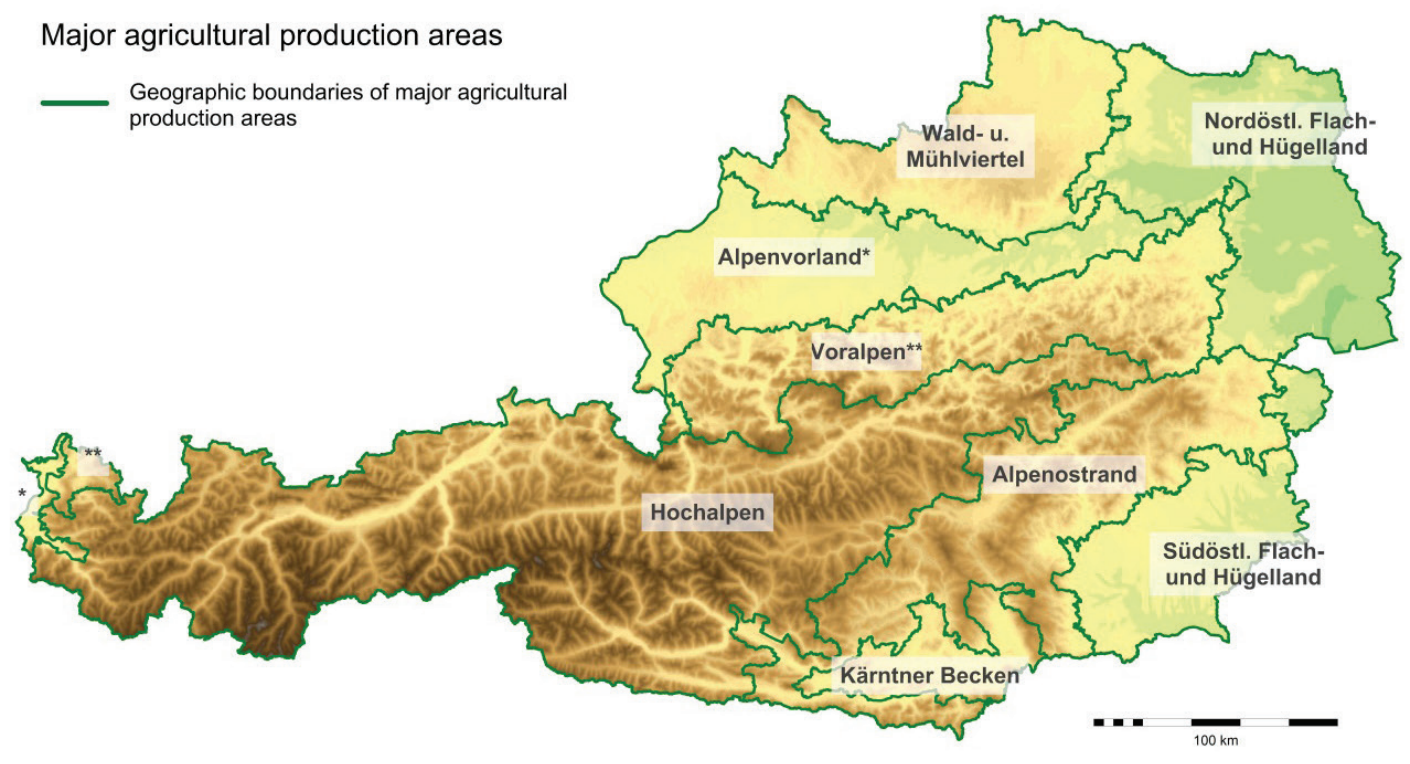

Figure 1. The eight major agricultural production areas in Austria (Wagner, 2016)

Abbildung 1. Die acht landwirtschaftlichen Hauptproduktionsgebiete in Österreich (Wagner, 2016) 
overrepresented in the sample. Therefore, the survey is not representative of crop yield quantities (tonnes) for the sum of Austrian organic holdings. Hence, we use the arable land data from the Austrian Integrated Administration and Control System (IACS) data set for extrapolations. Out of the 494 organic holdings, the number of holdings with organic arable land in the Austrian Farm Accountancy Data amounts to 242 in 2016 (224 in the year 2003). For sugar beet, we use a different data source originating from the association of the Austrian sugar beet farmers. This data source delivers average crop yields based on the majority of Austrian sugar beet farmers. The data is not available for a further subdivision into regional categories. Sugar beet is therefore excluded from the two analyses of regional categories, since it is only available on a national level.

\subsection{Regional and climatic specifications}

Crop yields generally depend on factors such as the amounts of nutrients, water and sunlight absorbed, weed and pest pressure, and the crops' genetic potential (OECD, 2014). These factors are highly contextual and may differ among natural land and site characteristics. The diverse topography and corresponding different agricultural preconditions make it necessary to further subdivide Austria into regions. First, a common classification of the Austrian agricultural landscape is its categorisation into major agricultural production areas. This classification is based on definitions by Schwackhöfer (1961), Steden and Schmittner (1951), and Wagner (1990a; 1990b) and takes into account natural land characteristics such as elevation and slope gradients as well as key characteristics of agricultural holdings, e.g., size and production activity (Binder and Pfingstner, 1988). In a second step, we only consider climatic conditions, taking into account conditions with high relevance for the growth of crops. We classify climatic agricultural areas (Figure 2) using the concept of the climatic water balance (CWB). The CWB describes the difference between precipitation and evapotranspiration (for a review, see Döring et al., 2011) of a specific region or area. Although, it does not include important input factors such as soil type, water storage capacity or surface runoff, the CWB is suitable for classifications of regions according to ecological criteria. We use the CWB because it takes into account the botanical requirements to a greater extent than a single parameter system (Harflinger and Knees, 1999) and represents an efficient and simple approach to characterise regions according to climatic conditions. The CWB-values used are provided by the Institute of Meteorology of the University of Natural Resources and Life Sciences Vienna (BOKU) at a municipality level for the period 2003-2015 (Eitzinger and Formayer, 2016). The climate data is derived from the data output generated by the weather prediction model INCA (see Haiden et al., 2011) which delivers climate data on a $1 \times 1 \mathrm{~km}$ grid and is maintained by the Zentralanstalt für Meteorologie and Geodynamik (ZAMG) in Vienna. The calculation of CWB-values is performed at grid level by dividing the mean annual precipitation by the mean annual potential evapotranspiration (PET). If there is more than one CWB-value per municipality, the minimum value is considered valid, assuming that the arable land is situated on the low-lying lands of a municipality. Calculated CWB-values range between $0.53-2.73$ for the area analysed. We classified the climatic areas into dry-, occasionally dry and humid areas in cooperation with BOKU (Formayer, 2016) and experts of the Austrian Chambers of Agriculture. As a result, we define the climatic agricultural areas with a CWB $\leq 0.75$ as dry areas, CWB $>0.75-1.25$ as occasionally dry and $>1.25$ as humid areas.

\subsection{Methodology}

We calculate weighted average crop yields per crop species for each regional category in both regional classifications on an annual basis as well as for the period 2003-2016. Considering the potentially higher productivity of larger holdings, we weight average crop yields of crop species by the respective acreage per crop species and holding in the respective region. To derive crop yields at a national level, we extrapolate the weighted average crop yields per major agricultural production area. Therefore, we use the corresponding amount of hectares per crop species. Amounts of arable land in hectares are obtained from the Austrian IACS data set. For certain major agricultural production areas, crop yield data is sensitive due to data security. Sensitive data issues occur when there are no or less than three crop yields per major agricultural production area and crop species. In those cases, the yield of respective crop species is estimated by the mean organic to conventional yield ratio over all major agricultural production areas, multiplied by the conventional crop yield of the corresponding regional category. By aggregating the quantities of crop yields of the major agricultural production areas, we derive total amounts of crop yields for Austria. To obtain the crop yields per crop species at a national level, those amounts are divided by the aggregated total amount of hectares per crop species. 


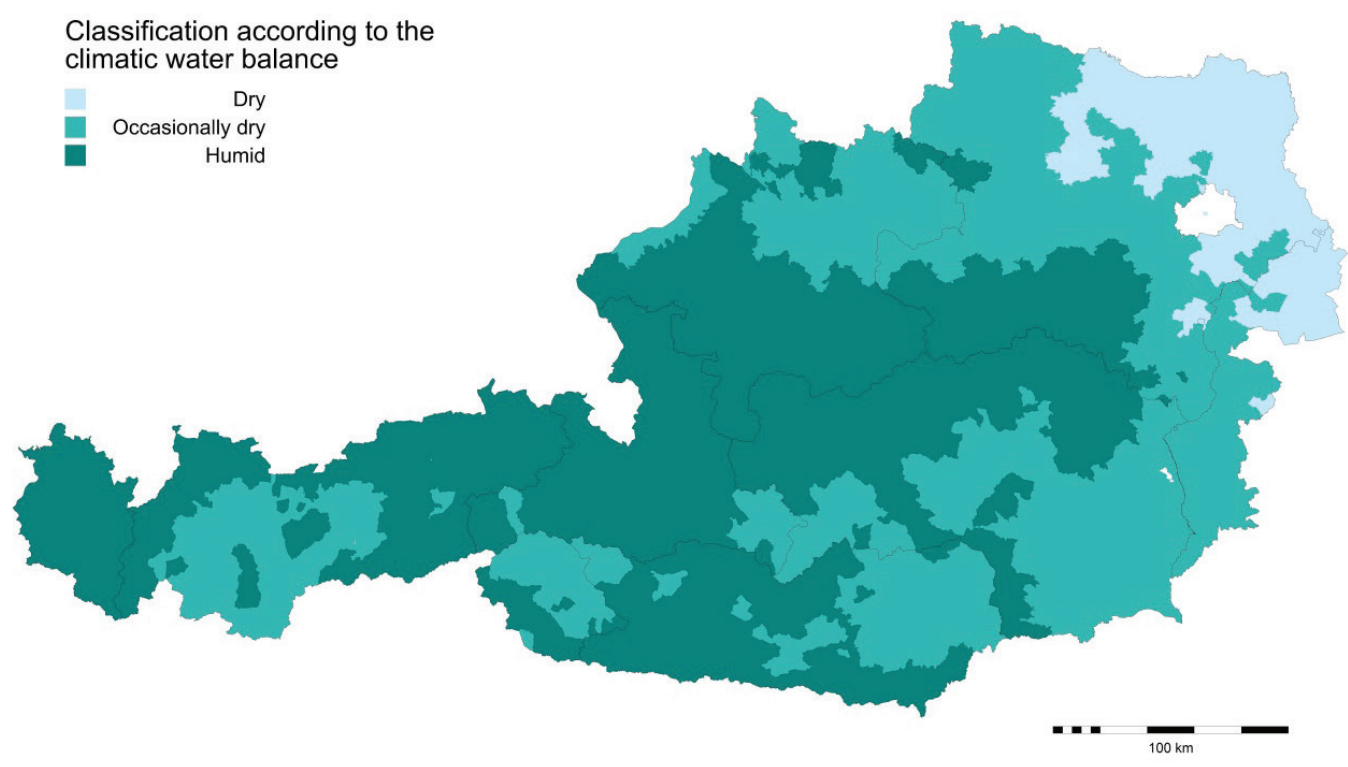

Figure 2. Climatic agricultural areas in Austria (own illustration, 2017) Abbildung 2. Landwirtschaftliche Klimagebiete in Österreich (eigene Darstellung, 2017)

We then compare the mean organic yields of several crops to conventional yields both at the national and the regional category level. We test the variations in annual crop yields, differences between average crop yields of regional categories and differences between organic and conventional crop yields. In addition, we analyse organic crop yield differences between regional categories and test for statistical significances. For this purpose, we perform the non-parametric Kruskal-Wallis test (a generalisation of the Mann-Whitney test), which is used for comparisons of more than two subgroups. This test ranks values of subgroups from the smallest (rank 1) to the largest value. The null hypothesis is that the compared groups have the same general distribution. So, if the medians of each group are equal, the values of each group should be similar (Sheskin, 2007; Johnson and Morgan, 2016). The alternative hypothesis is that if the medians of the compared groups are different, the distribution of one group differs. The significance level equates to $\alpha=0.05$. We complete the test, using the software package EViews.

\section{Results and Discussion}

For each crop species, we compare organic and conventional crop yields. The comparison shows differences in yields per hectare (Table 1). On average, organic cereal yields are 66\% of conventional yields. Organic root and tuber crop yields show more divergence, amounting to $50.9-72.8 \%$ of conventional root and tuber crop yields. Some oilseed and protein crops, however, tend to give yields closer to the level of conventional ones. For example, soybean is the crop with the smallest yield gap in our observation, producing average relative crop yields of $93.4 \%$. Overall, the organic crop yields examined show a high variation with standard deviations of between 33.8 and 60. We also observe organic crop species to have a higher relative variability of crop yields compared to conventional crop species (Figure 3), with the exception of spelt and potatoes. Results of organic and conventional crop yields in absolute terms (dt/ha) can be found in Annex 1.

Between regional categories, the results of our study confirm a significant difference in organic crop yields. This is true for both regional analyses, though it is not valid for every individual crop species. Moreover, the gaps between organic and conventional crop yields vary between regional categories (Annex 2 and Annex 3). The availability of crop yield data varies among the major agricultural production and climatic areas. In areas where arable agriculture is unfavourable, comparisons of organic to conventional crop yields are not feasible for every crop species due to the scarce number of recorded crop yields. 
Table 1. Organic crop yields per hectare compared to conventional crop yields per hectare based on weighted average crop yields during the period 2003-2016, national level

Tabelle 1. Bio-Erträge pro Hektar im Vergleich mit konventionellen Erträgen pro Hektar basierend auf gewichteten Erträgen in der Periode 2003-2016, bundesweit

\begin{tabular}{|c|c|c|c|c|}
\hline & $\begin{array}{l}\text { Relative yield organic vs. conventional } \\
\qquad(\%)\end{array}$ & $\begin{array}{c}\text { Standard deviation of organic national } \\
\text { yield }( \pm \%)^{3}\end{array}$ & $\mathrm{n}^{\circ}$ & $\mathrm{n}^{\mathrm{c}}$ \\
\hline \multicolumn{5}{|l|}{ Cereals } \\
\hline Common wheat & 64.2 & 33.8 & 1,433 & 10,999 \\
\hline Rye & 61.3 & 46.7 & 1,405 & 2,881 \\
\hline Winter barley & 58.9 & 39.1 & 543 & 7,990 \\
\hline Spring barley & 66.5 & 45.7 & 796 & 6,182 \\
\hline Oat & 68.4 & 44.6 & 1,046 & 2,998 \\
\hline Triticale & 68.5 & 36.2 & 1,422 & 4,877 \\
\hline Corn & 63.7 & 40.1 & 554 & 7,197 \\
\hline Spelt & 77.4 & 40.4 & 915 & 246 \\
\hline \multicolumn{5}{|c|}{ Root and tuber crops } \\
\hline Potatoes & 50.9 & 50.7 & 1,652 & 4,441 \\
\hline Sugar beets ${ }^{1}$ & 72.6 & & & \\
\hline \multicolumn{5}{|c|}{ Oilseed and protein crops } \\
\hline Oil pumpkin & 78.2 & 43.2 & 373 & 2,158 \\
\hline Field peas & 56.6 & 58.1 & 513 & 1,926 \\
\hline Faba beans ${ }^{2}$ & 70.8 & 60.3 & 348 & 419 \\
\hline Soybeans & 93.4 & 42.6 & 250 & 1,976 \\
\hline
\end{tabular}

$\mathrm{n}^{\mathrm{o}}=$ number of observations on organic farms from 2003-2016; $\mathrm{n}^{\mathrm{c}}=$ number of observations on conventional farms 2003-2016; yield data of sugar beets only available from 2008-2016; ${ }^{2}$ no organic data from 2003-2004 and no conventional data for 2008 ; ${ }^{3}$ unbalanced panel

Among the eight major agricultural production areas, our analysis reveals strong varying yield gaps between organic and conventional yields. Yet the organic crop yields show little variation of organic crop yields between those areas (see Annex 2 for specific information). We identified differences of organic crop yields between certain areas and crop species but not for crop types as such. For example, organic crop yields for cereals such as triticale and winter barley are significantly lower in the Nordöstliches Flach- and Hügelland compared to other major agricultural production areas. Conversely, common wheat and rye show similar or higher crop yields in the Nordöstliches Flach- and Hügelland. Organic rye and potato yields are the highest in the production area Wald- and Mühlviertel. The organic corn yields calculated are similar in the major production areas Alpenvorland, Südöstliches Flach- and Hügelland and Nordöstliches Flach- and Hügelland. Higher organic corn yields in other areas might be biased by smaller sample sizes.

Conventional crop yields vary considerably between production areas. This leads to substantially differing yield gaps between organic and conventional crops across production areas. For instance, the yield ratios of organic to conventional corn yields vary between 0.58 and 0.70 . One explanation for the variance across production areas is the potential yield and water-limited yield levels: i) the potential yield level is defined as the yield level with nutrients and water non-limiting, and an effective control of pests, weed, diseases and lodging. Therefore, the potential yield is only influenced by radiation, $\mathrm{CO}_{2}$ concentration and temperature (Evans and Fischer, 1999; van Ittersum et al., 2013). The closer the conventional crop yields get to this level, the greater the yield gap between organic and conventional crop yields will be (De Ponti et al., 2012); ii) The water-limited yield is restricted by water supply, thus influenced by the water holding capacity and rooting depth of the respective soil (FAO and DWFI, 2015). Taking into consideration that significant proportions of Austrian arable land are located in dry agricultural areas of central Europe (Harlfinger and Knees, 1999), water supply may be a yield limiting factor over time, causing smaller yield gaps 


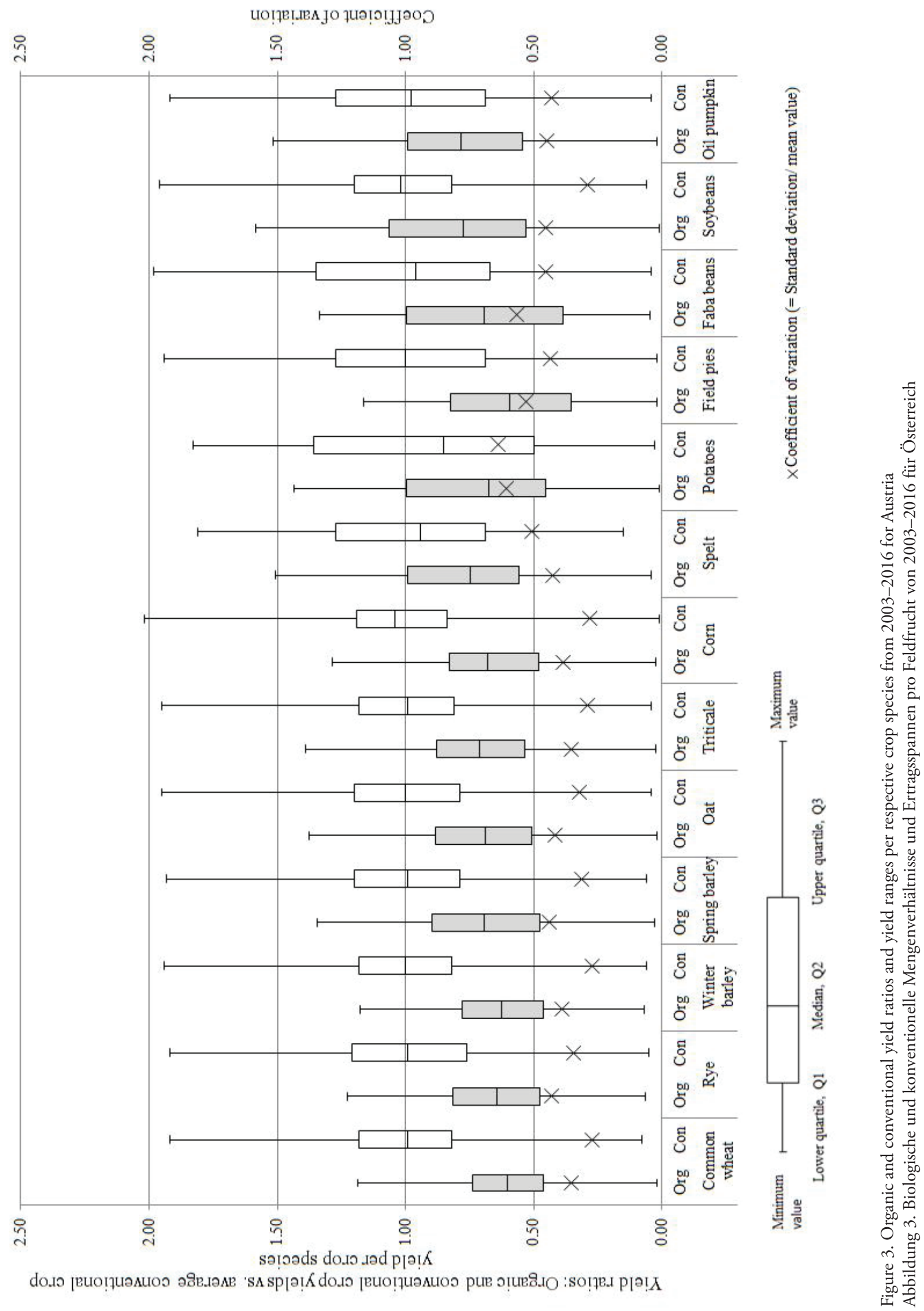


between organic and conventional crop yields. In Austria, the production areas Nordöstliches Flach- and Hügelland and parts of the Wald- and Mühlviertel would be affected. In climatic agricultural areas, the crop yield differences between regional categories become more obvious. In dry areas, the yield gap of major field crops such as common wheat or corn is substantially smaller than in humid or occasionally dry areas (see Annex 3 and Figure 4). Throughout our study, we can find statistically significant differences in organic crop yields between climatically diverse agricultural areas. For example, organic oil pumpkins do have high relative yield levels compared to conventional oil pumpkin yields in occasionally dry areas (79\%) and in dry areas (76\%). Furthermore, organic soybeans perform far above relative average yields and even exceed the level of conventional yields in dry areas by $9 \%$ (Figure 4), though results may be affected by small sample sizes. However, average organic rye, triticale and winter barley achieve respective highest crop yields in humid areas. Organic crop yields of rye and triticale are significantly higher compared to the occasionally dry areas and dry areas. The exception to this finding is that, not every individual crop species differs between the climatic agricultural areas. Overviews of all calculated crop yields are illustrated in Annex 3. For humid areas, crop species data with a small population should be considered carefully. Results might be affected by favourable local conditions in valleys of alpine areas and the various types of landscapes covered by humid areas. Generally, our results confirm that the yield gaps between organic and conventional crops are highly dependent on the location.

\section{Limitations}

The limitations of our analysis include challenges in sample sizes, limited detail of crop rotations, the use of onfarm data, and the knowledge held by those responsible for record keeping. Firstly, our analysis may be limited due to small sample sizes and highly variable sample sizes. This may lead to bias and a reduced accuracy of results, which could affect the reliability of calculated crop yields. Secondly, we do not account for the specific characteristics of organic crop rotations and their effects on estimated or-

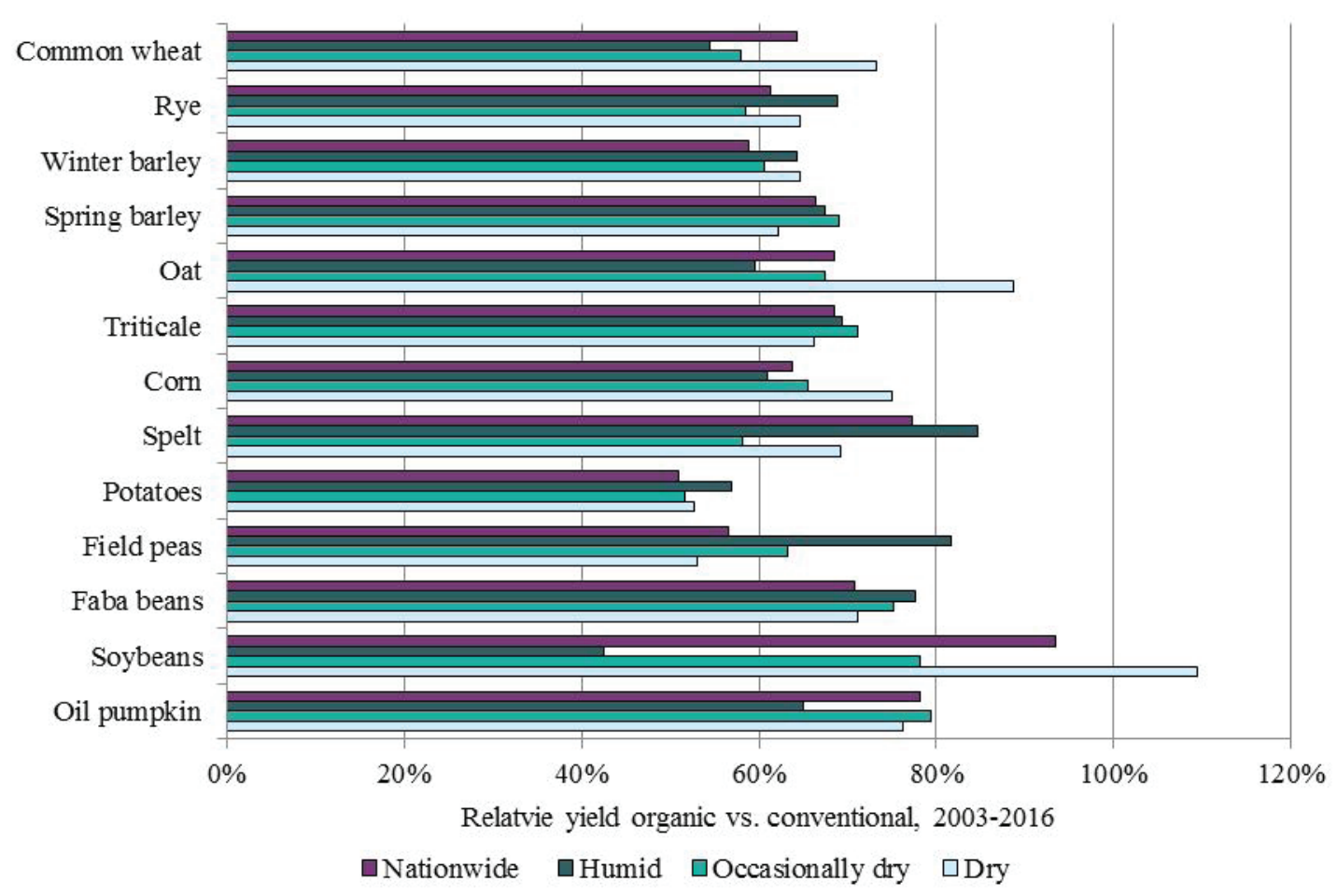

Figure 4. Relative yields organic vs. conventional, nationwide and climatic agricultural areas, 2003-2016

Abbildung 4. Relative Erträge biologisch vs. konventionell, bundesweit und auf landwirtschaftliche Klimagebietsebene, 2003-2016 
ganic crop yields. Next, we solely use on-farm data, which usually implies a lower level of accuracy regarding data recording and standardisation of farm operations. Therefore, an approach including on-station data could have increased the scope and depth of our analysis. Lastly, the heterogeneous level of knowledge and expertise of farmers may have an impact on cultivated crop yields.

\section{Conclusion}

Our analysis shows that for Austria relative organic crop yields are considerably lower than conventional ones. The yield gap between organic and conventional crop yields varies between crop species and regional categories. In some regional categories, the organic crop yields are almost at the level of conventional crop yields. Within crop types (cereals, root and tuber crops and oilseed and protein crops), there is a high variation of individual yield gaps; therefore, we cannot derive general assumptions for crop types. Nevertheless, the comparison of organic and conventional crop yields is controversial. This study does not compare organic and conventional farming systems by listing the advantageous and disadvantageous aspects of these farming systems. The comparison of individual crop yields is important for future production decisions, but does not compare organic with conventional farming systems based on various preconditions (e.g., ecological, economic and social aims). It would be useful to develop and extend our data set to give a broader and more accurate picture of the Austrian organic sector. Analysis of crop yield trends over time can depict different developments of organic and conventional crop yields. The interaction between reliable climate data and more accurate organic crop data could help the in-depth examination of significances and yield gaps between regional categories.

Actual organic crop yields and the yield gap might be further affected if we take into account crop rotations. Our study, however, compares organic and conventional crop yields based on average crop yields per crop species. Profitability calculations and nationwide estimations of crop yields focus on crop rotations rather than individual crop yields. One explanation for this is that in organic agriculture, a considerable component of crop rotation is nonmarketable crops. Non-marketable crops or green manure are necessary to add nitrogen to the system (De Ponti et al., 2012). Nonetheless, while fodder can be used for livestock and is exchanged for manure, at holdings without live- stock, the cultivation of those crops presents a major challenge. If we account for the non-marketable area within a crop rotation, the crop yields may be even lower (Gabriel et al., 2013). Consequently, we conducted a questionnaire focusing on the organic farm holders with arable land and without livestock. The survey aimed to develop a deeper insight into alfalfa and clover shares in crop rotations. The first results identified the share of alfalfa and clover to be $16 \%$ of the crop rotation on particular farms (Brückler et al., 2017). These percentages have to be considered if crop yield data is used for profitability calculations or for upscaling of crop yields on a nationwide level.

\section{Acknowledgements}

We would like to thank Josef Eitzinger and Herbert Formayer for their support with CWB-data and deeper insights in the area of climate data.

\section{References}

Binder J. and H. Pfingstner (1988): Neues Klassifizierungssystem für landwirtschaftliche Betriebe in Österreich. Agrarpolitische Arbeitsbehelfe der Bundesanstalt für Agrarwirtschaft Wien, pp. 50.

BMFLUW - The Austrian Federal Ministry of Agriculture, Forestry, Environment and Water Management (2011): Green Report. Vienna, pp. 204.

BMFLUW - The Austrian Federal Ministry of Agriculture, Forestry, Environment and Water Management (2017a): IACS - Integrated Administration and Control System 2017. Vienna.

BMFLUW - The Austrian Federal Ministry of Agriculture, Forestry, Environment and Water Management (2017b): Green Report. Vienna, pp. 162.

Brückler, M., Resl, T. and A. Reindl (2017): Mengenerträge im österreichischen Bio-Ackerbau. In: Green Report. 2017, BMFLUW - The Austrian Federal Ministry of Agriculture, Forestry, Environment and Water Management, Vienna, 50-51.

Darnhofer, I., Lindenthal, T., Bartel-Kratochvil and W. Zollitsch (2009): Conventionalisation of organic farming practices: from structural criteria towards an assessment based on organic principles - A review. Agronomy for Sustainable Development 30, 67-81. 
De Ponti, T., Rijk, B., and M.K. Van Ittersum (2012): The crop yield gap between organic and conventional agriculture. Agricultural Systems 108, 1-9.

Döring, S., Döring, J., Borg, H. and F. Böttcher (2011): Vergleich von Trockenheitsindizes zur Nutzung in der Landwirtschaft unter klimatischen Bedingungen Mitteldeutschlands. Hercynia N.F. 44, 145-168.

Eder, M. (2006): Der biologische Landbau in Österreich: Eine Erfolgsgeschichte - Organic farming in Austria: A success story. In: Darnhofer I., Walla, C. and H.K. Wytrzens (Eds.): Alternative Strategien für die Landwirtschaft. Facultas, Vienna, 89-100.

Eitzinger, J. and H. Formayer (2016, July 18): Written communication. University of Natural Rescources and Life Sciences Vienna, Vienna

Evans, L.T. and R.A. Fischer (1999): Yield potential - its definition, measurement and significance. Crop Science 39, 1544-1551.

European Commission (2013): Facts and figures on organic agriculture in the European Union. Directorate General for Agriculture and Rural Development, 1-45.

FAO and DWFI (2015): Yield gap analysis of field crops Methods and case studies. Water Reports 41, 1-82.

Formayer, H. (2016, July 26): Personal Communication, BOKU, Vienna.

Gabriel, D., Sait, S.M., Kunin, W.E. and T.G. Benton (2013): Food production vs. biodiversity - Comparing organic and conventional agriculture. Journal of Applied Ecology 50, 355-364.

Gattinger, A., Muller, A., Haeni, M., Skinner, C., Fliessbach, A., Buchmann, N., Mäder, P., Stolze, M., Smith, P., El-Hage Scialabba, N. and U. Niggli (2012): Enhanced top soil carbon stocks under organic farming. PNAS 109, 18226-18231.

Godfray, H.C.J., Beddington, J.R., Crute, I.R., Haddad L., Lawrence D., Muir J.F., Pretty J., Robinson S., Thomas S.M. and C. Toulmin (2010): Food Security - The Challenge of Feeding 9 Billion People. Science 327, 812-818.

Groier, M. (2013): Wie weit darf Bio gehen? Analyse von Konventionalisierungsrisiken im Bereich der biologischen Landwirtschaft Österreichs. Forschungsbericht 69, Bundesanstalt für Bergbauernfragen, Vienna, pp. 211.

Groier, M. (2016): Organic farming in Austria is family farming. Federal Institute for Less-Favoured and Mountainous Areas. https://berggebiete.at/cm3/de/down- load/viewdownload/19/549.html. Accessed on 19 April 2017.

Haiden, T., Kann, A., Wittmann, C., Pistotnik, G., Bica, B. and C. Gruber (2011): The Integrated Nowcasting through Comprehensive Analysis (INCA) system and its validation over the Eastern Alpine region. Weather and Forecasting 26, 166-183.

Harflinger, O., and G. Knees, (1999): Klimahandbuch der Österreichischen Bodenschätzung. Teil 1 Klimatographie, Wagner, Innsbruck.

Herndl, M., Baumgartner, D.U., Guggenberger, T. and M. Bystricky (2016): Umweltauswirkungen von ausgewählten Ackerbaubetrieben in Österreich: Beitragsanalyse und Verbesserungsoptionen Environmental impacts of selected arable farms in Austria: Contribution analysis and improvement options. In: Arbeitsgemeinschaft für Lebensmittel- Veterinär- und Agrarwesen (Ed.): ALVA Jahrestagung 2016: Eiweißpflanzen - Strategien und Chancen für Landwirtschaft und Industrie 71, RepaCopy, Vienna, 155-157.

Johnson R. and G.B. Morgan (2016): Survey Scales - A Guide to Development, Analysis, and Reporting. Guilford Press, New York, pp. 269.

Mäder P., Fließbach A., Dubois D., Gunst L., Fried, P. and U. Niggli (2002): Soil fertility and biodiversity in organic farming. Science 296, 1694-1697.

Mondelaers, K., Aertsens, J. and G.V. Huylendbroeck (2009): A meta-analysis of the differences in environmental impacts between organic and conventional farming. British Food Journal 111, 1098-1119.

Noleppa (2016): Pflanzenschutz in Deutschland und Biodiversität- Auswirkungen von Pflanzenschutzstrategien der konventionellen und ökologischen Landbewirtschaftung auf die regionale und globale Artenvielfalt. 1/2016, HFFA Research GmbH, Berlin, pp. 60.

OECD (2014): Crop production. http://dx.doi. org/10.1787/49a4e677-en. Accessed on 23 February 2017.

Osterburg, B., Kätsch, S. and A. Wolff (2013): Szenarioanalysen zur Minderung von Treibhausgasemissionen der deutschen Landwirtschaft im Jahr 2015. In: Johann Heinrich von Thünen-Institut (Ed.): Thünen Rep 13. Braunschweig, pp. 132.

Schneeberger, W., Eder, M., Darnhofer, I., Walla, C. and W. Zollitsch (2005): Stand des biologischen Landbaus in Österreich. Eigenverlag, Universität für Bodenkultur Wien, pp. 39. 
Schwackhöfer, W. (1966): Die landwirtschaftlichen Kleinproduktionsgebiete Österreichs. Der Förderungsdienst - Zeitschrift für Lehr- und Beratungskräfte, Sonderheft 3, Bundesministerium für Land- und Forstwirtschaf, pp. 149.

Seufert V., Ramankutty N. and J.A. Foley (2012): Comparing the yields of organic and conventional agriculture, Nature, 229-231.

Sheskin, D. (2007): Handbook of parametric and nonparametric statistical procedures. $4^{\text {th }}$ ed., Taylor $\&$ Francis Ltd, London, pp. 1736.

Steden, A. and F. Schmittner (1951): Die Produktionsgebiete Österreichs. Die Bodenkultur 5, 397-416.

Tuck S.L., Winqvist, C., Mota, F., Ahnström, J., Turnbull, L.A. and J. Bengtsson (2014): Land-use intensity and the effects of organic farming on biodiversity: a hierarchical meta-analysis. Journal of Applied Ecology 51, 746-755.

Tuomisto, H.L., Hodge, I.D., Riordan, P. and D.W. Macdonald (2012): Does organic farming reduce environ- mental impacts? A meta-analysis of European research. Journal of Environmental Management 112, 309-320. Van Ittersum, M. K., Cassman, K. G., Grassini, P., Wolf, J., Tittonell, P. and Z. Hochman (2013): Yield gap analysis with local to global relevance - A review. Field Crops Research 143, 4-17.

Wagner K. (1990): Neuabgrenzung landwirtschaftlicher Produktionsgebiete in Österreich Teil I. In: Bundesanstalt für Agrarwirtschaft (Ed.): Schriftenreihe 62. Bundesanstalt für Agrarwirtschaft (AWI), Wien, pp. 324.

Wagner K. (1990): Neuabgrenzung landwirtschaftlicher Produktionsgebiete in Österreich Teil II. In: Bundesanstalt für Agrarwirtschaft (Ed.): Schriftenreihe 62. Bundesanstalt für Agrarwirtschaft (AWI), Wien, 325-574.

Von Witzke, H. and S. Noleppa (2013): Der gesamtgesellschaftliche Nutzen von Pflanzenschutz in Deutschland Darstellung des Projektansatzes und von Ergebnissen zu Modul 1 - Ermittlung von Markteffekten und gesamtwirtschaftlicher Bedeutung. Industrieverband Agrar, Frankfurt, pp. 44. 
Annex 1. Average weighted crop yields, nationwide (2003-2016)

Anhang 1. Durchschnittliche gewichtete Erträge, bundesweit (2003-2016)

\begin{tabular}{|c|c|c|c|c|}
\hline & & \multirow{2}{*}{\multicolumn{3}{|c|}{ Austria }} \\
\hline & & & & \\
\hline & & Org & Conv & Rel.* \\
\hline \multirow[t]{2}{*}{ Common wheat } & $\mathrm{dt} / \mathrm{ha}$ & 35.4 & 55.1 & $64 \%$ \\
\hline & $\mathrm{n}$ & 1,433 & 10,999 & \\
\hline \multirow[t]{2}{*}{ Rye } & $\mathrm{dt} / \mathrm{ha}$ & 26.2 & 43.0 & $61 \%$ \\
\hline & $\mathrm{n}$ & 1,405 & 2,881 & \\
\hline \multirow[t]{2}{*}{ Winter barley } & $\mathrm{dt} / \mathrm{ha}$ & 33.3 & 56.4 & $59 \%$ \\
\hline & $\mathrm{n}$ & 543 & 7,990 & \\
\hline \multirow[t]{2}{*}{ Spring barley } & $\mathrm{dt} / \mathrm{ha}$ & 27.6 & 41.6 & $67 \%$ \\
\hline & $\mathrm{n}$ & 796 & 6,182 & \\
\hline \multirow[t]{2}{*}{ Oat } & $\mathrm{dt} / \mathrm{ha}$ & 28.2 & 41.2 & $68 \%$ \\
\hline & $\mathrm{n}$ & 1,046 & 2,998 & \\
\hline \multirow[t]{2}{*}{ Triticale } & $\mathrm{dt} / \mathrm{ha}$ & 35.3 & 51.6 & $69 \%$ \\
\hline & $\mathrm{n}$ & 1,422 & 4,877 & \\
\hline \multirow[t]{2}{*}{ Corn } & $\mathrm{dt} / \mathrm{ha}$ & 60.4 & 94.6 & $64 \%$ \\
\hline & $\mathrm{n}$ & 554 & 7,197 & \\
\hline \multirow[t]{2}{*}{ Spelt } & $\mathrm{dt} / \mathrm{ha}$ & 25.5 & 34.1 & $77 \%$ \\
\hline & $\mathrm{n}$ & 915 & 246 & \\
\hline \multirow[t]{2}{*}{ Potatoes } & $\mathrm{dt} / \mathrm{ha}$ & 173.9 & 341.9 & $51 \%$ \\
\hline & $\mathrm{n}$ & 1,652 & 4,441 & \\
\hline \multirow[t]{2}{*}{ Sugar beets ${ }^{1}$} & $\mathrm{dt} / \mathrm{ha}$ & 512.8 & 695.2 & $73 \%$ \\
\hline & $\mathrm{n}$ & & & \\
\hline \multirow[t]{2}{*}{ Field peas } & $\mathrm{dt} / \mathrm{ha}$ & 13.3 & 23.5 & $57 \%$ \\
\hline & $\mathrm{n}$ & 373 & 2,158 & \\
\hline \multirow[t]{2}{*}{ Faba beans ${ }^{2}$} & $\mathrm{dt} / \mathrm{ha}$ & 16.4 & 26.8 & $71 \%$ \\
\hline & $\mathrm{n}$ & 513 & 1,926 & \\
\hline \multirow[t]{2}{*}{ Soybeans } & $\mathrm{dt} / \mathrm{ha}$ & 22.3 & 25.7 & $93 \%$ \\
\hline & $\mathrm{n}$ & 348 & 419 & \\
\hline \multirow[t]{2}{*}{ Oil pumpkin } & $\mathrm{dt} / \mathrm{ha}$ & 4.3 & 5.7 & $78 \%$ \\
\hline & $\mathrm{n}$ & 250 & 1,976 & \\
\hline
\end{tabular}

$\mathrm{dt} / \mathrm{ha}=$ weighted average yield in decitonnes per hectare; $\mathrm{n}=$ number of documented yield data between $2003-2016$; ${ }^{*}$ Relative yields organic to conventional; ' yield data of sugar beets only available from 2008-2016; ${ }^{2}$ no organic data from 2003-2004; ${ }^{2}$ no conventional data for 2008 


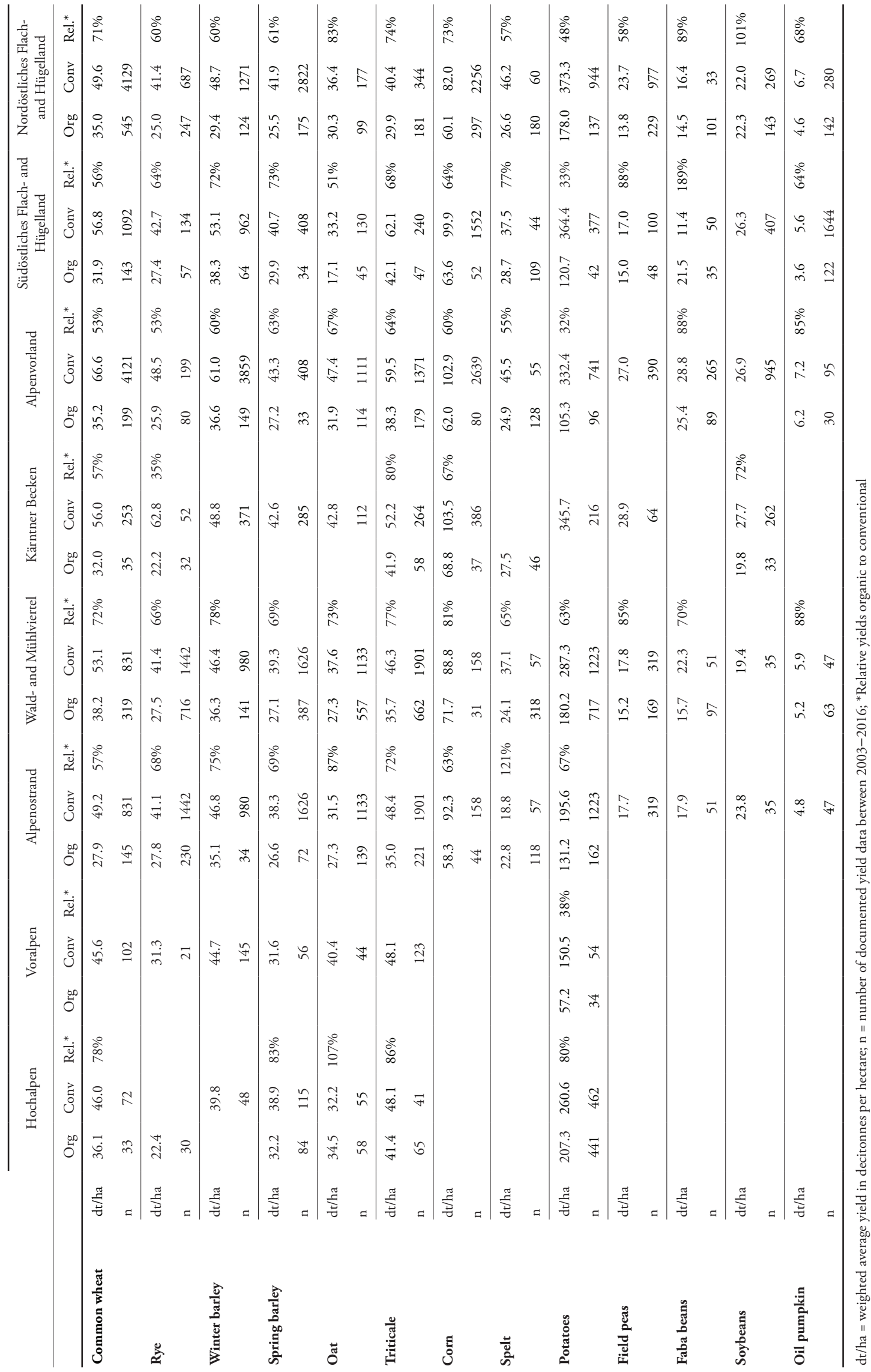


Annex 3. Average weighted crop yields per climatic agricultural area (2003-2016)

Anhang 3. Mittlere gewichtete Erträge pro landwirtschaftlichem Klimagebiet (2003-2016)

\begin{tabular}{|c|c|c|c|c|c|c|c|c|c|c|}
\hline & & \multicolumn{3}{|c|}{ Humid } & \multicolumn{3}{|c|}{ Occasionally dry } & \multicolumn{3}{|c|}{ Dry } \\
\hline & & Org & Conv & Rel. $^{*}$ & Org & Conv & Rel. $^{*}$ & Org & Conv & Rel.* \\
\hline \multirow[t]{2}{*}{ Common wheat } & $\mathrm{dt} / \mathrm{ha}$ & 35.4 & 65.1 & $54 \%$ & 33.9 & 58.4 & $58 \%$ & 36.4 & 49.7 & $73 \%$ \\
\hline & $\mathrm{n}$ & 156 & 1999 & & 809 & 5924 & & 450 & 3063 & \\
\hline \multirow[t]{2}{*}{ Rye } & $\mathrm{dt} / \mathrm{ha}$ & 31.6 & 45.9 & $69 \%$ & 25.8 & 44.1 & $58 \%$ & 26.4 & 40.7 & $65 \%$ \\
\hline & $\mathrm{n}$ & 182 & 368 & & 1019 & 1945 & & 191 & 558 & \\
\hline \multirow[t]{2}{*}{ Winter barley } & $\mathrm{dt} / \mathrm{ha}$ & 37.6 & 58.5 & $64 \%$ & 34.8 & 57.3 & $61 \%$ & 32.2 & 49.8 & $65 \%$ \\
\hline & $\mathrm{n}$ & 117 & 2214 & & 339 & 4947 & & 87 & 820 & \\
\hline \multirow[t]{2}{*}{ Spring barley } & $\mathrm{dt} / \mathrm{ha}$ & 26.9 & 39.9 & $67 \%$ & 27.8 & 40.4 & $69 \%$ & 26.6 & 42.6 & $62 \%$ \\
\hline & $\mathrm{n}$ & 90 & 672 & & 544 & 3121 & & 154 & 2384 & \\
\hline \multirow[t]{2}{*}{ Oat } & $\mathrm{dt} / \mathrm{ha}$ & 26.3 & 44.2 & $60 \%$ & 28.1 & 41.7 & $67 \%$ & 30.0 & 33.8 & $89 \%$ \\
\hline & $\mathrm{n}$ & 172 & 936 & & 805 & 1971 & & 67 & 90 & \\
\hline \multirow[t]{2}{*}{ Triticale } & $\mathrm{dt} / \mathrm{ha}$ & 38.8 & 56.0 & $69 \%$ & 36.4 & 51.2 & $71 \%$ & 31.0 & 46.8 & $66 \%$ \\
\hline & $\mathrm{n}$ & 277 & 1359 & & 997 & 3287 & & 143 & 221 & \\
\hline \multirow[t]{2}{*}{ Corn } & $\mathrm{dt} / \mathrm{ha}$ & 60.9 & 100.0 & $61 \%$ & 64.1 & 97.8 & $66 \%$ & 58.6 & 78.1 & $75 \%$ \\
\hline & $\mathrm{n}$ & 42 & 1042 & & 249 & 4611 & & 254 & 1529 & \\
\hline \multirow[t]{2}{*}{ Spelt } & $\mathrm{dt} / \mathrm{ha}$ & 21.7 & 25.6 & $85 \%$ & 23.9 & 41.1 & $58 \%$ & 27.5 & 39.8 & $69 \%$ \\
\hline & $\mathrm{n}$ & 90 & 54 & & 637 & 138 & & 184 & 54 & \\
\hline \multirow[t]{2}{*}{ Potatoes } & $\mathrm{dt} / \mathrm{ha}$ & 165.1 & 289.7 & $57 \%$ & 175.6 & 339.6 & $52 \%$ & 188.4 & 357.4 & $53 \%$ \\
\hline & $\mathrm{n}$ & 484 & 1206 & & 1051 & 2498 & & 113 & 733 & \\
\hline \multirow[t]{2}{*}{ Field peas } & $\mathrm{dt} / \mathrm{ha}$ & & 26.7 & & 14.2 & 22.5 & $63 \%$ & 13.4 & 25.3 & $53 \%$ \\
\hline & $\mathrm{n}$ & & 228 & & 282 & 942 & & 206 & 755 & \\
\hline \multirow[t]{2}{*}{ Faba beans } & $\mathrm{dt} / \mathrm{ha}$ & 23.4 & 30.2 & $78 \%$ & 18.5 & 24.7 & $75 \%$ & 13.3 & & \\
\hline & $\mathrm{n}$ & 35 & 149 & & 226 & 247 & & 78 & & \\
\hline \multirow[t]{2}{*}{ Soybeans } & $\mathrm{dt} / \mathrm{ha}$ & & 26.4 & & 20.7 & 26.5 & $78 \%$ & 24.5 & 22.4 & $109 \%$ \\
\hline & $\mathrm{n}$ & & 396 & & 136 & 1438 & & 107 & 140 & \\
\hline \multirow[t]{2}{*}{ Oil pumpkin } & $\mathrm{dt} / \mathrm{ha}$ & & & & 4.5 & 5.7 & $79 \%$ & 4.7 & 6.1 & $76 \%$ \\
\hline & $\mathrm{n}$ & & & & 203 & 1883 & & 162 & 251 & \\
\hline
\end{tabular}

$\mathrm{dt} / \mathrm{ha}=$ weighted average yield in decitonnes per hectare; $\mathrm{n}$ = number of documented yield data between 2003-2016;

*Relative yields organic vs. conventional 